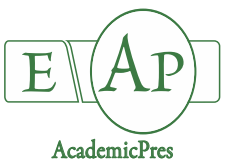

Ulczycka-Walorska M et al. (2020)

Notulae Botanicae Horti Agrobotanici Cluj-Napoca 48(1):398-405

DOI: $10.15835 /$ nbha48111748

Research Article

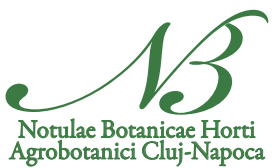

\title{
Response of Hyacinthus orientalis L. to salinity caused by increased concentrations of sodium chloride in the soil
}

\section{Maria ULCZYCKA-WALORSKA ${ }^{1}$, Agnieszka KRZYMIŃSKA ${ }^{2 *}$, Hanna BANDURSKA ${ }^{3}$, Jan BOCIANOWSKI ${ }^{4}$}

\author{
${ }^{1}$ Voivodeship Plant Health and Seed Inspection, Grunwaldzka 250, 60-166 Poznań, Poland; mulczycka@op.pl \\ ${ }^{2}$ Poznań University of Life Sciences, Department of Ornamental Plants, Dąbrowskiego 159, 60-594 Poznań, \\ Poland; agnieszka.krzyminska@up.poznan.pl (*corresponding author) \\ ${ }^{3}$ Poznań University of Life Sciences, Department of Plants Physiology, Wotyn'ska 35, 60-637 Poznań, \\ Poland; hanna.bandurska@up.poznan.pl \\ ${ }^{4}$ Poznań University of Life Sciences, Department of Mathematical and Statistical Methods, Wojska Polskiego 28, 60-637 Poznań, \\ Poland;jan.bocianowski@up.poznan.pl
}

\begin{abstract}
Hyacinths are used in flowerbed in cities. Plants are exposed to difficult urban conditions prevailing in winter, including notably to soil salinity resulting mainly from the use of sodium chloride. The aim of the study was analysed the response of Hyacinthus orientalis 'Delft Blue' to increased concentrations of sodium chloride in the soil. Pots with bulbs were each treated with $100 \mathrm{~cm}^{3}$ of $\mathrm{NaCl}$ aqueous solution at a concentration of either $10 \mathrm{~g} \mathrm{dm}^{-3}$ (dose level 1) or $20 \mathrm{~g} \mathrm{dm}^{-3}$ (dose level 2). Pots were irrigated with the $\mathrm{NaCl}$ aqueous solution in September or in January of the following year. After keeping the bulbs at a cool temperature for 12 weeks, the plants were grown in a greenhouse where they were assessed in terms of growth parameters and free proline content. The obtained results showed that the growth and the ornamental qualities of Hyacinthus orientalis 'Delft Blue' after treatment with sodium chloride were sufficient for recommending this plant for growing in flower beds exposed to salinity of $6.1-8.6 \mathrm{~g} \mathrm{dm}^{-3}$. The leaf greenness index and proline content (in the second season) were greater and the length of forcing period was longer (in the second season), when the sodium chloride was applied to the soil on the day of planting bulbs.
\end{abstract}

Keywords: bulbous plants; bulbs; flower bed; $\mathrm{NaCl}$; proline

\section{Introduction}

Hyacinthus orientalis is a bulbous plant frequently used as a component of floral arrangements growing in spring flower beds in green spaces. Hyacinthus orientalis flowers in spring on stems growing from underground bulbs planted earlier in autumn. This makes it particularly exposed to difficult urban conditions prevailing in winter, including notably to soil salinity resulting mainly from the use of sodium chloride $(\mathrm{NaCl})$ to remove ice from roads and pavements.

Salt stress induces various physiological disorders in plants (Parida and Das, 2005). Basically, salinity exerts a twofold negative influence on plants. The increased concentration of ions in the soil solution decreases 
soil water potential thus triggering osmotic stress, which hinders water intake from the soil. This results in lower water content in cells, cell turgor loss, and stunted plant growth (Liang et al., 2018). This process also involves stomata closure, which reduces carbon dioxide diffusion inside leaves and inhibits photosynthesis (Parihar et al., 2015). The above changes slow down plant growth, limit biomass accumulation and disturb the plant development process (Gharsallah et al., 2016).

Another harmful effect resulting from increased $\mathrm{NaCl}$ concentrations in the soil is an increased uptake of $\mathrm{Na}^{+}$and $\mathrm{Cl}$, which disrupts ion metabolism and causes ionic stress (Teh et al., 2016; Mansour and Ali, 2017). The consequence is disturbance in the absorption of potassium, phosphorus, calcium and nitrogen ions leading to insufficient levels of those elements in the plant (Chinnusamy et al., 2006; Teh et al., 2016; Mansour and Ali, 2017). The aforementioned changes as well as the toxic effect of sodium and chlorine ions on the activity of various enzymes disrupt many metabolic pathways and damage cellular structures (Chinnusamy et al., 2006). The negative influence of the increased concentration of sodium and chlorine ions manifests as lower chlorophyll content in leaves and, finally, in chlorosis (Tavakkoli et al., 2010). The above described disturbances cause changes in plant morphology, delayed flowering, accelerated aging and an earlier loss of the plant's ornamental value (Ramoliya et al., 2004). The toxicity of those ions is also apparent through premature defoliation, and in extreme cases, even plant death (Läuchli and Grattan, 2007).

A plant may use two strategies to develop resistance to stress factors, including salinity; namely, it may either avoid or tolerate stress (Chinnusamy et al., 2006; Parihar et al., 2015; Singh et al., 2017). Avoiding salt stress involves the formation of protective barriers to prevent harmful ions from invading the cytoplasm and the maintenance of the osmotic balance to prevent cell dehydration. Salt tolerance is a response to salinity by triggering mechanisms that limit damage and enable damage repair. Such mechanisms are linked to the synthesis of specific proteins and compatible substances that enable maintaining the osmotic balance in cells and protect cell structures from the consequences of dehydration and ionic toxicity (Mansour and Ali, 2017). One of such substances is an amino acid called proline, the level of which increases in many plant species exposed to salinity (Hayat et al., 2012; Gharsallah et al., 2016). It was shown that both the accumulation and exogenous application of proline under salt stress conditions improved plant resistance to this adverse environmental factor (Hayat et al., 2012; Teh et al., 2016; Mansour and Ali, 2017). Proline increases tolerance to salinity in that it reduces the cell water potential and thus prevents dehydration. In addition, this amino acid may protect cell structures and enzymes from damage caused by dehydration and the toxicity of ions (Hayat $e t$ al., 2012; Mansour and Ali, 2017). Proline may also scavenge reactive oxygen species, which are produced during times of stress, disturb metabolic processes (Hayat et al., 2012).

The aim of this study was to investigate the response of Hyacinthus orientalis 'Delft Blue', an ornamental plant with a magnificent and fragrant inflorescence, to salinity caused by increased $\mathrm{NaCl}$ concentrations in the soil. The study analysed the influence of two dose levels of sodium chloride applied on two different dates on the plant's resistance to salinity and the content of free proline in leaves. Resistance to salinity was assessed based on growth parameters (stem length, dry matter of the aerial part) and ornamental qualities (flowering start date, leaf greenness index (SPAD)).

\section{Materials and Methods}

The experiment was conducted in the greenhouse of the Department of Ornamental Plants at the Poznań University of Life Sciences during two seasons (2014/15 and 2015/16). Bulbs of Hyacinthus orientalis 'Delft Blue' were planted in calendar week 34 in $0.8 \mathrm{dm}^{3}$ flower pots filled with a peat substrate of $\mathrm{pH} 6.2$ (measured after the addition of minerals). The potting medium was enriched with the following mineral components of the soil: $146 \mathrm{mg} \mathrm{dm}^{-3} \mathrm{~N}_{-N_{3}}, 47 \mathrm{mg} \mathrm{dm}^{-3} \mathrm{~N}_{-N_{4}}, 65 \mathrm{mg} \mathrm{dm}^{-3} \mathrm{P}, 321 \mathrm{mg} \mathrm{dm}^{-3} \mathrm{~K}, 1840 \mathrm{mg} \mathrm{dm}$ 
${ }^{3} \mathrm{Ca}, 145 \mathrm{mg} \mathrm{dm}^{-3} \mathrm{Mg}, 64 \mathrm{mg} \mathrm{dm}^{-3} \mathrm{Na}, 36 \mathrm{mg} \mathrm{dm}^{-3} \mathrm{Cl}$. Soil salinity in terms of $\mathrm{NaCl}$ content was $1.9 \mathrm{gdm}^{-3}$. The soil $\mathrm{pH}$ and salinity were measured using conductometer CPC-511 (Elmetron).

There were 140 pots in the experiment, each containing one bulb. The pots were divided into five treatments, 28 pots per treatment, as follows: (1) control, (2) a $10 \mathrm{~g} \mathrm{dm}^{-3}$ aqueous solution of $\mathrm{NaCl}$ (dose level 1) applied on the bulb planting date, (3) a $10 \mathrm{~g} \mathrm{dm}^{-3}$ aqueous solution of $\mathrm{NaCl}$ (dose level 1) applied in the first week of January, (4) a $20 \mathrm{~g} \mathrm{dm}^{-3}$ aqueous solution (dose level 2) of $\mathrm{NaCl}$ applied on the bulb planting date, (5) a $20 \mathrm{~g} \mathrm{dm}^{-3}$ aqueous solution of $\mathrm{NaCl}$ (dose level 2) applied in the first week of January.

On the planting date, the soil and the bulbs in 84 pots were watered with $100 \mathrm{~cm}^{3}$ of tap water. The remaining pots were each irrigated with $100 \mathrm{~g} \mathrm{dm}^{-3}$ of NaCl aqueous solution at a concentration of $10 \mathrm{gdm}^{-3}$ (28 pots) and $20 \mathrm{~g} \mathrm{dm}^{-3}$ (28 pots). The pots with the bulbs were placed for 12 weeks in a room with an initial temperature of $+9^{\circ} \mathrm{C}$ to let them grow roots and prepare them for cultivation. In December the temperature was reduced to $+5{ }^{\circ} \mathrm{C}$, and in January to $+2{ }^{\circ} \mathrm{C}$ so as to avoid elongated plant growth. In the first week of January, 56 pots earlier watered with tap water were selected of which 28 pots were irrigated with $10 \mathrm{gdm}^{-3}$ $\mathrm{NaCl}$ aqueous solution and another 28 pots with $20 \mathrm{~g} \mathrm{dm}^{-3} \mathrm{NaCl}$ aqueous solution. The remaining pots were watered with $100 \mathrm{~cm}^{3}$ of tap water.

\section{Soil salinity}

After applying $10 \mathrm{~g} \mathrm{dm}^{-3} \mathrm{NaCl}$ aqueous solution, the soil salinity level was $6.1 \mathrm{~g} \mathrm{dm}^{-3}$, and the content of $\mathrm{Na}$ and $\mathrm{Cl}$ in $1 \mathrm{dm}^{-3}$ of the soil was, respectively, $134 \mathrm{mg}$ and $2192 \mathrm{mg}$. Irrigation with $20 \mathrm{~g} \mathrm{dm}^{-3} \mathrm{NaCl}$ aqueous solution resulted in a soil salinity level of $8.6 \mathrm{~g} \mathrm{dm}^{-3}$, with $\mathrm{Na}$ and $\mathrm{Cl}$ concentrations of $233 \mathrm{mg} \mathrm{dm}^{-3}$ and 3646 $\mathrm{mg} \mathrm{dm}{ }^{-3}$, respectively. In both cases, the $\mathrm{pH}$ value was 6.3.

\section{Determination of proline content}

Seven days before the planned date of moving the plants to the greenhouse, four pots with plants were selected from each treatment to determine proline content in leaves. Proline content was measured in 4 replications, and each replication was conducted on a different plant material sample. Proline content was measured according to Bates et al. (1973).

\section{Greenhouse growing, observations and measurements}

After the 12-week cooling period, the plants were moved to the greenhouse. The experiment involved 5 treatments, each including 24 pots. The number of pots per treatment was reduced by 4 pots which were earlier selected for the proline content measurement. One pot with bulb was one replication.

Water loss from pots placed in the greenhouse was replenished using tap water irrigation. In this process, pots with plants were weighed and supplemented with water until all pots had the same weight.

In both seasons, plants were grown in the greenhouse from 10 January to 5 April, i.e. till the end of flowering. During that time, the number of growing days until the beginning of flowering was determined. On the flowering start date, the stem length was measured from the base to the place of growth of the bottom-most flower. After the flowering, the dry matter of the aerial part was weighed.

The chlorophyll content was measured using the leaf greenness index (Test Soil Plant Analysis System SPAD) (Pacewicz and Gregorczyk, 2009). At the beginning and after flowering, SPAD values were determined using a Yara $\mathrm{N}$-tester. Based on the results, the percentage difference between the initial and final value was calculated. The measurement was conducted on the apex of the external leaf of each plant in a treatment.

\section{Statistical analysis}

The results were subjected to a two-way analysis of variance using Statistica software, while means were grouped using the Duncan test at the significance level $\alpha=0.05$. For percentage values, the normality of distribution of the studied features was checked using the Shapiro-Wilk normality test. A Bliss transformation $\left(y=\arcsin (x / 100)^{-1 / 2}\right.$, where $y$-value of a characteristic after transformation, $x$-observed value of the trait before 
transformation) was performed in the case of abnormal feature distribution. In the remaining cases, the data were subjected to the standard Duncan test. The data were compared in each season separately.

\section{Results and Discussion}

The number of days that Hyacinthus orientalis 'Delft Blue' needed to start flowering in both seasons depended on the dose level of $\mathrm{NaCl}$ applied in the experiment (Table 1). The control plants were the first to start flowering. The length of exposure to the stress factor was significant only in the second season. The application of sodium chloride on the bulb planting date delayed flowering. Such response to saline conditions has been observed in many plant species, e.g rice (Läuchli and Grattan, 2007), China aster (Kücükahmetler, 2002) and narcissus (Veatch-Blohm et al., 2014).

Introducing the stress factor resulted in weaker plant growth in the saline soil (Table 2). The length of the stem on the flowering start date depended only on the soil salinity level. The longest stems were found in the control group and the shortest in the group subjected to dose level 2 of $\mathrm{NaCl}$. It can be concluded that, $\mathrm{NaCl}$ inhibited growth, as was the case in Gaillardia aristata and Salvia coccinea (Niu and Rodriguez, 2006). Nevertheless, the inflorescence was fully developed and showed no signs of damage. Hyacinthus 'Delft Blue' is suitable for planting in soils with salinity of up to $8.6 \mathrm{~g} \mathrm{dm}^{-3}$ of $\mathrm{NaCl}$.

In the first season, the percent change in the SPAD value depended solely on the applied $\mathrm{NaCl}$ dose level (Table 3). The percent change in the SPAD value increased in the control treatment and after dose level 1 of $\mathrm{NaCl}$, whereas it decreased after dose level 2 of $\mathrm{NaCl}$. In the second season, the SPAD value percent change was positive and depended on both the $\mathrm{NaCl}$ dose level and the date of its application. The highest growth in the SPAD value was noted in the control treatment, and the lowest growth was observed after dose level 2 of $\mathrm{NaCl}$. Irrigating the soil with the $\mathrm{NaCl}$ solution on the date of bulb planting led to a stronger increase in the percent change in SPAD value relative to the $\mathrm{NaCl}$ treatment in the first week of January. These results suggest that 'Delft Blue' is less resistant to high $\mathrm{NaCl}$ doses when applied later in the season, similar to Calceolaria bybrida, Calendula officinalis (Fornes et al., 2007), Vicia faba (Tavakkoli et al., 2010) and in research of Türkoglu et al. (2011). Rajesh et al. (1998) showed that the chlorophyll content of salinity resistent plants increased under the influence of $\mathrm{NaCl}$.

The weight of the dry matter of the aerial part collected after flowering depended only on the applied $\mathrm{NaCl}$ dose level in both seasons (Table 4). In the first season the weight of the dry matter obtained from the control treatment was higher than that from plants treated with dose levels 1 and 2 of $\mathrm{NaCl}$. In the second season, the dry matter of control plants and plants treated with dose level $1 \mathrm{NaCl}$ had a higher weight compared to that of plants treated with dose level 2 of $\mathrm{NaCl}$. This might indicate that 'Delft Blue' adapted to difficult environmental conditions or that sodium chloride might stimulate its growth. The speculation is confirmed by the study conducted by Niu and Rodriguez (2006). Different results were obtained by Rajesh et al. (1998). The fresh and dry matter of Ceriops roxburghiana was found to increase under salinity stress conditions.

The free proline content in young leaves was equal in both seasons and depended on both the $\mathrm{NaCl}$ dose level and the date of its application (Table 5). The plants treated with $\mathrm{NaCl}$ on the bulb planting date accumulated more free proline than the plants irrigated with the $\mathrm{NaCl}$ solution in the first week of January. The highest proline concentration was observed after dose level 2 of $\mathrm{NaCl}$ and the lowest - after dose level 1 of $\mathrm{NaCl}$. Also, the proline content in young leaves increased with the length of exposure to the stress factor. Similar observations were made in the studies on Atriplex halimus (Martinez et al., 2005), Trachyspermum ammi (Ashraf and Orooj, 2006), Iris lactea var. chinensis (Bai et al., 2008), Melisa officinalis (Khalid and Cai, 2011), Echium amoenum (Ramezani et al., 2011) and Crocus sativus (Rajaei et al., 2009; Renau-Morata et al., 2012). The results of this study seem to confirm that 'Delft Blue', like some other plant species, builds up resistance to $\mathrm{NaCl}$ by accumulating proline (Hayat et al., 2012; Teh et al., 2016; Mansour and Ali, 2017). 
Table 1. The number of days of pre-flowering period of Hyacinthus orientalis 'Delft Blue' in greenhouse by timing of exposure to $\mathrm{NaCl}$ and $\mathrm{NaCl}$ dose $(\mathrm{n}=24)$

\begin{tabular}{|c|c|c|c|c|c|c|c|c|}
\hline \multirow{2}{*}{$\begin{array}{c}\text { Term of } \mathrm{NaCl} \\
\text { application }\end{array}$} & \multicolumn{5}{|c|}{ Teason } \\
\cline { 2 - 9 } & \multicolumn{4}{|c|}{ The first } & \multicolumn{4}{c|}{ The second } \\
\cline { 2 - 9 } & 0 & 1 & 2 & Mean & 0 & 1 & 2 & Mean \\
\hline $\begin{array}{c}\text { The day of } \\
\text { planting bulbs }\end{array}$ & $18.4^{\mathrm{a}}$ & $19.7^{\mathrm{b}}$ & $20.0^{\mathrm{b}}$ & $19.3^{\mathrm{a}}$ & $17.9 \mathrm{a}$ & $20.4 \mathrm{bc}$ & $21.4 \mathrm{c}$ & $19.9 \mathrm{~b}$ \\
\hline $\begin{array}{c}\text { The } 1^{\text {st }} \text { week of } \\
\text { Jan. }\end{array}$ & $18.4 \mathrm{a}$ & $19.6 \mathrm{~b}$ & $19.8 \mathrm{~b}$ & $19.3 \mathrm{a}$ & $17.9 \mathrm{a}$ & $18.3 \mathrm{a}$ & $20.0 \mathrm{~b}$ & $18.7 \mathrm{a}$ \\
\hline Mean & $18.4 \mathrm{a}$ & $19.7 \mathrm{~b}$ & $19.9 \mathrm{~b}$ & & $17.9 \mathrm{a}$ & $19.3 \mathrm{~b}$ & $20.7 \mathrm{c}$ & \\
\hline
\end{tabular}

Dose level $1-10 \mathrm{~g} \mathrm{dm}^{-3}$ aqueous solution of $\mathrm{NaCl}$, dose level $2-20 \mathrm{~g} \mathrm{dm}^{-3}$ aqueous solution.

The means followed by the same letter do not differ significantly at $\alpha=0.05$.

Table 2. The length of Hyacinthus orientalis 'Delft Blue' stem in the beginning of flowering by timing of exposure to $\mathrm{NaCl}$ and $\mathrm{NaCl}$ dose $(\mathrm{n}=24)(\mathrm{cm})$

\begin{tabular}{|c|c|c|c|c|c|c|c|c|}
\hline \multirow{2}{*}{$\begin{array}{c}\text { Term of } \mathrm{NaCl} \\
\text { application }\end{array}$} & \multicolumn{9}{|c|}{ The first } & \multicolumn{4}{c|}{ The second } \\
\cline { 2 - 9 } & \multicolumn{4}{|c|}{ Dose level of $\mathrm{NaCl}$} & \multicolumn{4}{c|}{ Dose level of $\mathrm{NaCl}$} \\
\cline { 2 - 9 } & 0 & 1 & 2 & Mean & 0 & 1 & 2 & Mean \\
\hline $\begin{array}{c}\text { The day of planting } \\
\text { bulbs }\end{array}$ & $17.0^{\mathrm{c}}$ & $15.3^{\mathrm{b}}$ & $13.0^{\mathrm{a}}$ & $15.1^{\mathrm{a}}$ & $13.3^{\mathrm{b}}$ & $10.7^{\mathrm{ab}}$ & $8.3^{\mathrm{a}}$ & $10.8^{\mathrm{a}}$ \\
\hline The $1^{\text {st }}$ week of Jan. & $17.0^{\mathrm{c}}$ & $15.3^{\mathrm{b}}$ & $13.0^{\mathrm{a}}$ & $15.1^{\mathrm{a}}$ & $13.3^{\mathrm{b}}$ & $12.0^{\mathrm{b}}$ & $9.0^{\mathrm{a}}$ & $11.4^{\mathrm{a}}$ \\
\hline Mean & $17.0^{\mathrm{c}}$ & $15.3^{\mathrm{b}}$ & $13.0^{\mathrm{a}}$ & & $13.3^{\mathrm{c}}$ & $11.3^{\mathrm{b}}$ & $8.7^{\mathrm{a}}$ & \\
\hline
\end{tabular}

Dose level $1-10 \mathrm{gdm}^{-3}$ aqueous solution of $\mathrm{NaCl}$, dose level $2-20 \mathrm{~g} \mathrm{dm}^{-3}$ aqueous solution.

The means followed by the same letter do not differ significantly at $\alpha=0.05$.

Table 3. The change of leaf greenness index (SPAD value) of Hyacinthus orientalis 'Delft Blue' by timing of exposure to $\mathrm{NaCl}$ and $\mathrm{NaCl}$ dose $(\mathrm{n}=24)(\%)$

\begin{tabular}{|c|c|c|c|c|c|c|c|c|}
\hline \multirow{3}{*}{$\begin{array}{c}\text { Term of } \mathrm{NaCl} \\
\text { application }\end{array}$} & \multicolumn{9}{|c|}{ The first } & \multicolumn{4}{c|}{ The second } \\
\cline { 2 - 9 } & \multicolumn{4}{|c|}{ Dose level of NaCl } & \multicolumn{4}{c|}{ Dose level of $\mathrm{NaCl}$} \\
\cline { 2 - 9 } & 0 & 1 & 2 & Mean & 0 & 1 & 2 & Mean \\
\hline $\begin{array}{c}\text { The day of planting } \\
\text { bulbs }\end{array}$ & $1.5^{\mathrm{c}}$ & $2.4^{\mathrm{c}}$ & $-3.7^{\mathrm{ab}}$ & $0.1^{\mathrm{a}}$ & $11.2^{\mathrm{b}}$ & $10.4^{\mathrm{b}}$ & $3.7^{\mathrm{a}}$ & $8.4^{\mathrm{b}}$ \\
\hline The 1 $1^{\text {st }}$ week of Jan. & $1.5^{\mathrm{c}}$ & $-0.7^{\mathrm{bc}}$ & $-4.7^{\mathrm{a}}$ & $-1.3^{\mathrm{a}}$ & $11.2^{\mathrm{b}}$ & $3.3^{\mathrm{a}}$ & $4.2^{\mathrm{a}}$ & $6.2^{\mathrm{a}}$ \\
\hline Mean & $1.5^{\mathrm{b}}$ & $0.8^{\mathrm{b}}$ & $-4.2^{\mathrm{a}}$ & & $11.2^{\mathrm{c}}$ & $6.8^{\mathrm{b}}$ & $3.9^{\mathrm{a}}$ & \\
\hline
\end{tabular}

Dose level $1-10 \mathrm{~g} \mathrm{dm}^{-3}$ aqueous solution of $\mathrm{NaCl}$, dose level $2-20 \mathrm{~g} \mathrm{dm}^{-3}$ aqueous solution.

The means followed by the same letter do not differ significantly at $\alpha=0.05$. 
Table 4. The dry matter of the aerial part of Hyacinthus orientalis 'Delft Blue' after the end of flowering by timing of exposure to $\mathrm{NaCl}$ and $\mathrm{NaCl}$ dose $(\mathrm{n}=24)(\mathrm{g})$

\begin{tabular}{|l|c|c|c|c|c|c|c|c|}
\hline \multirow{2}{*}{\begin{tabular}{c}
\multirow{2}{*}{$\begin{array}{c}\text { Term of } \\
\text { application }\end{array}$} \\
\cline { 2 - 10 }
\end{tabular}} & \multicolumn{4}{|c|}{ The first } & \multicolumn{4}{c|}{ The second } \\
\cline { 2 - 10 } & \multicolumn{3}{|c|}{ Dose level of NaCl level of $\mathrm{NaCl}$} \\
\hline & 0 & 1 & 2 & Mean & 0 & 1 & 2 & Mean \\
\hline $\begin{array}{l}\text { The day of planting } \\
\text { bulbs }\end{array}$ & $6.0^{\mathrm{b}}$ & $4.8^{\mathrm{a}}$ & $5.0^{\mathrm{a}}$ & $5.3^{\mathrm{a}}$ & $4.8^{\mathrm{b}}$ & $4.3^{\mathrm{ab}}$ & $3.8^{\mathrm{a}}$ & $4.3^{\mathrm{a}}$ \\
\hline The 1 $1^{\text {st }}$ week of Jan. & $6.0^{\mathrm{b}}$ & $5.5^{\mathrm{ab}}$ & $5.5^{\mathrm{ab}}$ & $5.7^{\mathrm{a}}$ & $4.8^{\mathrm{b}}$ & $4.3^{\mathrm{ab}}$ & $3.5^{\mathrm{a}}$ & $4.2^{\mathrm{a}}$ \\
\hline Mean & $6.0^{\mathrm{b}}$ & $5.2^{\mathrm{a}}$ & $5.3^{\mathrm{a}}$ & & $4.8^{\mathrm{b}}$ & $4.3^{\mathrm{b}}$ & $3.7^{\mathrm{a}}$ & \\
\hline
\end{tabular}

Dose level $1-10 \mathrm{~g} \mathrm{dm}^{-3}$ aqueous solution of $\mathrm{NaCl}$, dose level $2-20 \mathrm{~g} \mathrm{dm}^{-3}$ aqueous solution.

The means followed by the same letter do not differ significantly at $\alpha=0.05$.

Table 5. The proline content in young leaves of Hyacinthus orientalis 'Delft Blue' by timing of exposure to $\mathrm{NaCl}$ and $\mathrm{NaCl}$ dose $(\mathrm{n}=4)\left(\mathrm{mgg}^{-1} \mathrm{FM}\right)$

\begin{tabular}{|c|c|c|c|c|c|c|c|c|}
\hline \multirow{3}{*}{$\begin{array}{c}\text { Term of } \\
\text { application }\end{array}$} & \multicolumn{9}{|c|}{ The first } & \multicolumn{4}{c|}{ The second } \\
\cline { 2 - 9 } & \multicolumn{4}{|c|}{ Dose level of $\mathrm{NaCl}$} & \multicolumn{4}{c|}{ Dose level of $\mathrm{NaCl}$} \\
\cline { 2 - 9 } & 0 & 1 & 2 & Mean & 0 & 1 & 2 & Mean \\
\hline $\begin{array}{c}\text { The day of planting } \\
\text { bulbs }\end{array}$ & $0.52^{\mathrm{bc}}$ & $0.42^{\mathrm{a}}$ & $0.96^{\mathrm{d}}$ & $0.63^{\mathrm{b}}$ & $0.52^{\mathrm{bc}}$ & $0.42^{\mathrm{a}}$ & $0.96^{\mathrm{d}}$ & $0.63^{\mathrm{b}}$ \\
\hline The $1^{\mathrm{st}}$ week of Jan. & $0.52^{\mathrm{bc}}$ & $0.56^{\mathrm{c}}$ & $0.49^{\mathrm{b}}$ & $0.52^{\mathrm{a}}$ & $0.52^{\mathrm{bc}}$ & $0.56^{\mathrm{c}}$ & $0.49^{\mathrm{b}}$ & $0.52^{\mathrm{a}}$ \\
\hline Mean & $0.52^{\mathrm{b}}$ & $0.49^{\mathrm{a}}$ & $0.73^{\mathrm{c}}$ & & $0.52^{\mathrm{b}}$ & $0.49^{\mathrm{a}}$ & $0.73^{\mathrm{c}}$ & \\
\hline
\end{tabular}

Dose level $1-10 \mathrm{gdm}^{-3}$ aqueous solution of $\mathrm{NaCl}$, dose level $2-20 \mathrm{gdm}^{-3}$ aqueous solution.

The means followed by the same letter do not differ significantly at $\alpha=0.05$.

\section{Conclusions}

Plants used in urban flower beds should be able to flower for a long period and look decorative even under unfavourable soil and climatic conditions. A proper selection of plant species and cultivars is particularly important when it comes to designing spring floral arrangements including bulb plants. The experiment described in this study showed that the growth and the ornamental qualities of Hyacinthus orientalis 'Delft Blue' after treatment with sodium chloride were sufficient for recommending this plant for growing in flower beds exposed to salinity of 6.1-8.6 g dm $\mathrm{gm}^{-3}$. The leaf greenness index and proline content (in the second season) were bigger and the length of forcing period was longer (in the second season), when the sodium chloride was applied to the soil on the day of planting bulbs.

\section{Acknowledgements}

The publication was financed within the framework of Ministry of Science and Higher Education programme as "Regional Initiative Excellence" in years 2019-2022, Project No. 005/RID/2018/19.

\section{Conflict of Interests}

The authors declare that there are no conflicts of interest related to this article. 


\section{References}

Ashraf M, Orooj A (2006). Salt stress effects on growth, ion accumulation and seed oil concentration in an arid zone traditional medicinal plant ajwain (Trachyspermum ammi [L.] Sprague). Journal of Arid Environments 64:209-220. https://doi.org/10.1016/j.jaridenv.2005.04.015

Bates L, Waldren R, Teare I (1973). Rapid determination of free proline for water-stress studies. Plant and Soil 39:205-207. https://doi.org/10.1007/BF00018060

Bai WB, Li PF, Li BG, Fujiyama H, Fan FC (2008). Some physiological responses of Chinese iris to salt stress. Pedosphere 18(4):454-463. https://doi.org/10.1016/S1002-0160(08)60036-3

Chinnusamy V, Zhu J, Zhu JK (2006). Salt stress signaling and mechanism of plant salt tolerance. Genetic Engineering 27:141177. https://doi.org/10.1007/0-387-25856-6_9

Fornes F, Belda RM, Carrión C, Noguera V, García-Augustín P, Abad M (2007). Pre-conditioning ornamental plants to drought by means of saline water irrigation as related to salinity tolerance. Scientia Horticulturae 113:52-59. https://doi.org/10.1016/j.scienta.2007.01.008

Gharsallah C, Fakhfakh H, Grubb D, Gorsane F (2016). Effect of salt stress on ion concentration, proline content, antioxidant enzyme activities and gene expression in tomato cultivars. AoB Plants 8:055. https://doi.org/10.1093/aobpla/plw055

Hayat S, Hayat Q, Alymeni MN, Wani AS, Pichtel J, Ahmed A (2012). Role of proline under changing environments. Plant Signal and Behaviour 7(11):1456-1466. https://doi.org/10.4161/psb.21949

Khalid KA, Cai W (2011). The effect of mannitol and salinity stresses on growth and biochemical accumulations in lemon balm. Acta Ecologica Sinica 31:112-120. https://doi.org/10.1016/j.chnaes.2011.01.001

Kücükahmetler Ö (2002). The effects of salinity on yield and quality of ornamental plants and cut flowers. Acta Horticulturae 573:407-414. https://doi.org/10.17660/ActaHortic.2002.573.49

Läuchli A, Grattan SR (2007). Plant stress and development under salinity stress. In: Jenks MA, Hasegawa PM, Jain SM (EDS). Advances in molecular breeding toward drought and salt tolerant crops. Dordrecht, Springer pp 1-32.

Liang W, Ma X, Wan P, Liu L (2018). Plant salt-tolerance mechanism: a review. Biochemical and Biophysical Research Communications 495:286-291. https://doi.org/10.1016/j.bbrc.2017.11.043

Mansour MMF, Ali EF (2017). Evaluation of proline functions in saline conditions. Phytochemistry 140:52-68. https://doi.org/10.1016/j.phytochem.2017.04.016

Martinez JP, Kinet JM, Bajji M, Lutts S (2005). NaCl alleviates polyethylene glycol-induced water stress in the halophyte species Atriplex halimus L. Journal of Experimental Botany 56(419):2421-2431. https://doi.org/10.1093/jxb/eri235

Niu G, Rodriguez DS (2006). Relative of salt tolerance of selected herbaceous perennials and groundcovers. Scientia Horticulturae 110:352-358. https://doi.org/10.1016/j.scienta.2006.07.020

Pacewicz K, Gregorczyk A (2009). Porównanie ocen zawartości chlorofilu chlorofilometrami SPAD-502 i N-Tester [Comparison of values of the chlorophyll content by chlorophyllmeter SPAD-502 and N-Tester]. Folia Pomeranae Universitatis Technologiae Stetinensis, Agricultura, Alimentaria, Piscaria et Zootechnica 269:41-46.

Parida AK, Das AB (2005). Salt tolerance and salinity effects on plants: a review. Ecotoxicology and Environmental Safety 60:324-349. https://doi.org/10.1016/j.ecoenv.2004.06.010

Parihar P, Singh S, Singh R, Singh VP, Prasad SM (2015). Effect of salinity stress on plants and its tolerance strategies: a review. Environmental Science and Pollution Research 22:4056-4075. https://doi.org/10.1007/s1 1356-014-3739-1

Rajaei SM, Niknam V, Sezedi SM, Ebrahimyadeh H, Rayavi K (2009). Contractile roots are the most sensitive organ in Crocus sativus to salt stress. Biologia Plantarum 53(3):523-529. https://doi.org/10.1007/s10535-009-0095-y

Rajesh A, Arumugam R, Venkatesalu V (1998). Growth and photosynthetic characteristics of Ceriops roxburghiana under $\mathrm{NaCl}$ stress. Photosynthetica 35(2):285-287. https://doi.org/10.1023/A1006983411991

Ramezani E, Sepaniou MG, Badi HAN (2011). The effect of salinity on the growth, morphology and physiology of Echium amoenum Fisch. \& Mey. African Journal of Biotechnology 10(44):8765-8773. http://dx.doi.org/10.5897/AJB10.2301

Ramoliya PJ, Patel HM, Pandey AN (2004). Effect of salinisation of soil on growth and macro- and micro- nutrient accumulation in seedlings of Acacia catechu (Mimosaceae). Annals of Applied Biology 144:321-332. https://doi.org/10.1111/j.1744-7348.2004.tb00347.x 
Renau-Morata B, Gebauer SG, Sánchez M, Molina RV (2012). Effect of corm size, water stress and cultivation conditions on photosynthesis and biomass partitioning during the vegetative growth of saffron (Crocus sativus L.). Industrial Crops and Products 39:40-46. https://doi.org/10.1016/j.indcrop.2012.02.009

Singh M, Singh A, Prasad SM, Singh RK (2017). Regulation of plants metabolism in response to salt stress: an omics approach. Acta Physiologiae Plantarum 39:48. https://doi.org/10.1007/s11738-016-2345-x

Tavakkoli E, Rengasamy P, McDonald GK (2010). High concentrations of $\mathrm{Na}^{+}$and $\mathrm{Cl}$ ions in soil solution hale simultaneous detrimental effects on growth of faba bean under salinity stress. Journal of Experimental Botany 61(15):4449-4459. https://doi.org/10.1093/jxb/erq251

Teh CY, Shaharuddin NA, Ho CL, Mahmood M (2016). Exogenous proline significantly affects the plant growth and nitrogen assimilation enzymes activities in rice (Oryza sativa) under salt stress. Acta Physiologiae Plantarum 38:151. https://doi.org/10.1007/s11738-016-2163-1

Türkoglu N, Erez ME, Battal P (2011). Determination of physiological responses on hyacinth (Hyacinthus orientalis) plant exposed to different salt concentrations. African Journal of Biotechnology 10(32):6045-6051. https://doi.org/10.5897/AJB10.2271

Veatch-Blohm ME, Sawch D, Elia N, Pinciotti D (2014). Salinity tolerance of three commonly planted Narcissus cultivars. HortScience 49(9):1158-1164. https://doi.org/10.21273/HORTSCI.49.9.1158

OPEN ACCESS

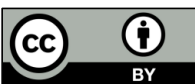

The journal offers free, immediate, and unrestricted access to peer-reviewed research and scholarly work. Users are allowed to read, download, copy, distribute, print, search, or link to the full texts of the articles, or use them for any other lawful purpose, without asking prior permission from the publisher or the author.

License - Articles published in Notulae Botanicae Horti Agrobotanici Cluj-Napoca are Open-Access, distributed under the terms and conditions of the Creative Commons Attribution (CC BY 4.0) License. (C) Articles by the authors; UASVM, Cluj-Napoca, Romania. The journal allows the author(s) to hold the copyright/to retain publishing rights without restriction. 